Grand Valley State University

ScholarWorks@GVSU

$5-22-2020$

\title{
Present at the Destruction? Grand Strategy Imperatives of US Foreign Policy Experts During the Trump Presidency
}

Hermann Kurthen

Grand Valley State University, kurthenh@gvsu.edu

Follow this and additional works at: https://scholarworks.gvsu.edu/soc_articles

Part of the American Politics Commons, International Relations Commons, and the Public Affairs, Public Policy and Public Administration Commons

\section{ScholarWorks Citation}

Kurthen, Hermann, "Present at the Destruction? Grand Strategy Imperatives of US Foreign Policy Experts During the Trump Presidency" (2020). Peer Reviewed Articles. 12.

https://scholarworks.gvsu.edu/soc_articles/12

This Article is brought to you for free and open access by the Sociology Department at ScholarWorks@GVSU. It has been accepted for inclusion in Peer Reviewed Articles by an authorized administrator of ScholarWorks@GVSU. For more information, please contact scholarworks@gvsu.edu. 


\section{Present at the Destruction? Grand Strategy Imperatives of US Foreign Policy Experts During the Trump Presidency}

\begin{tabular}{|c|l|}
\hline Journal: & European Journal of International Security \\
\hline Manuscript ID & EJIS-0046-19.R2 \\
\hline Keywords: & $\begin{array}{l}\text { US grand strategy, Foreign policy elite, Qualitative interviews, Abductive } \\
\text { reconstructivist methodology, Trump nationalism, Blob }\end{array}$ \\
\hline Abstract: & $\begin{array}{l}\text { This article discusses the grand strategy imperatives of 37 foreign policy } \\
\text { experts in Washington, DC. in response to President Donald Trump's } \\
\text { nationalist challenge to the post-WWII international order concept. Using } \\
\text { an abductive reconstructivist methodology to analyze in-depth } \\
\text { interviews, five grand strategy imperatives or rules for action shared by } \\
\text { all actors were identified: safeguarding US global leadership, maintaining } \\
\text { alliances, securing US prosperity, value orientation, and the belief in a } \\
\text { mission. Based on the interpretation of these rules for action, four types } \\
\text { of foreign policy experts were distinguished: nationalists, realists, } \\
\text { pragmatic liberals, and liberals. The latter three expert types, also } \\
\text { labelled globalists, were united in their opposition to the nationalists' } \\
\text { demolition of the international order but divided along partisan and } \\
\text { ideological lines about the meaning and implementation of the rules for } \\
\text { action. Realists, pragmatic liberals, and liberals were also unsure of how } \\
\text { to explain and respond to Trump's nationalism beyond a defensive or } \\
\text { wishful hope to save the vestiges of an US-centric international order. } \\
\text { The findings demonstrate the value of in-depth qualitative interviews for } \\
\text { explaining elite beliefs, illustrating the rich insights for policy analysis } \\
\text { that can be gained through this methodology. }\end{array}$ \\
\hline
\end{tabular}

\section{SCHOLARONE Manuscripts}




\section{Introduction}

The election of President Donald Trump in 2016 signaled a shift in the US toward an outspoken nationalistic foreign policy, setting the country on a path of potential disagreements with many of its traditional allies and away from the rules-based international order paradigm of previous decades. ${ }^{1}$ This change recently led some senior academic opinion-shapers and non-mainstream think tank experts to question the foundations of the postwar order grand strategy, ${ }^{2}$ specifically the long-term sustainability of maintaining US

1 There is no space here to review the literature about the international order concept in detail. For a short summary of the evolution of this order, see Rebecca Friedman Lissner and Mira Rapp-Hooper, 'The Day after Trump: American Strategy for a New International Order,' The Washington Quarterly, 4:1 (2018), p. 7-25. Other summaries and critiques have been published by Andrew Moravcsik, 'Taking Preferences seriously: A Liberal Theory of International Politics,' International Organization, 51:4 (1997), p. 513-53; Daniel Deudney and G. John Ikenberry, 'The Nature and Sources of Liberal International Order,' Review of International Studies, 25:2 (1999), p.179-96; Knud Erik Jørgensen, 'Liberal Internationalism,' in Knud Erik Jørgensen et al. eds., SAGE Handbook of European Foreign 
global primacy through instruments like the current alliance system, trade agreements, military interventions, and export of US values. These critics ${ }^{3}$ argue that it is increasingly impractical and unrealistic to continue the US foreign policy of the post-WWII and postCold War period given the global trends toward a multi-centric realignment of powers, the

Policy (London: Sage, 2013), pp. 501-15; G. John Ikenberry, Liberal Leviathan: The Origins, Crisis, and Transformation of the American World Order (Princeton, NJ: Princeton University Press, 2011); Graham Allison, 'The Myth of the Liberal Order: From Historical Accident to Conventional Wisdom,' Foreign Affairs, 97:4 (2018), pp. 124-33; Christopher Layne, 'The US Foreign Policy establishment and Grand Strategy: How American Elites obstruct Strategic Adjustment,' International Politics, 54:3 (2017), pp. 260-75.

${ }^{2}$ In this study the use of the term "grand strategy" is focused on foreign policy only and excludes, for analytical reasons, the domestic arena. Here grand strategy is defined as the 'means and ends to produce national security.... [and] a sense of national identity...about the nation's role and position in world politics.' Georg Löfflmann, 'From the Obama Doctrine to America First: The Erosion of the Washington Consensus on Grand Strategy,' International Politics, 20:1 (2019), pp. 2-3. According to Posen, grand strategy is based on a 'a quiet consensus among the foreign and security policy elite,' see Barry Posen, 'Command 
legacies of self-inflicted US foreign policy mistakes in recent history, the long-term erosion of the country's economic and technological clout, and the creeping loss of public trust in the US elites' leadership capability, their policies, and values.

This critique of the fundamentals of the liberal world order, however, has not been heeded by many members of the foreign policy community, including not only foreign policy think tank policy analysts but also media commentators, diplomats, members of the State Department, Congressional staffers, and other experts in federal agencies, lobby organizations, and academia. After Trump's inauguration, most of these foreign policy elite

of the Commons: The Military Foundation of US Hegemony,' International Security, 28:1 (2003), pp. 19-20.

${ }^{3}$ See, for example, John Mearsheimer, 'Bound to Fail: The Rise and Fall of the Liberal International Order,' International Security, 43:4. (2019), pp. 7-50; Charles L. Glaser, 'A Flawed Framework: Why the Liberal International Order Concept Is Misguided,' 43:4 (2019), pp. 51-87; John Mearsheimer, The Great Delusion: Liberal Dreams and International Realities (New Haven, CT: Yale University Press, 2018); Ivo H. Daalder and James M. Lindsay, The Empty Throne: America's Abdication of Global Leadership (New York: Public Affairs, 2018); G. John Ikenberry, 'The End of Liberal International Order?' 
were not in the mood to discuss or develop a new substance and direction for US foreign policy in recognition of ongoing global changes. ${ }^{4}$ Seeing the foundations of the existing rules-based order under assault by President Donald Trump, they fell back into a defensive modus operandi because they did not want to be "present at the destruction" of an order that - in their views - had worked so well in the past. ${ }^{5}$ This raises the question why, now and then, many members of the foreign policy community are reticent to critically evaluate US grand strategy during a time when the enormous shifts in domestic and international relations demand new answers. ${ }^{6}$

International Affairs, 94:1 (2018), pp. 7-23; Joseph S. Nye, 'The Rise and Fall of American Hegemony from Wilson to Trump,' International Affairs, 95:1 (2019), pp. 63-80. Ted Galen Carpenter, Gullible Superpower (Washington, DC: Cato Institute, 2019); Stephen M. Walt, The Hell of Good Intentions: America's Foreign Policy Elite and the Decline of US Primacy (New York: Farrar, Straus and Giroux, 2018); Richard Haass, A World in Disarray: American Foreign Policy and the Crisis of the Old Order (New York: Penguin Press, 2017); Andrew J. Bacevich, The New American Militarism: How Americans Are Seduced by War, 
The fact that the US foreign policy community was caught unprepared by Trump's nationalist "revolution," their perceived bystander mentality, and their intellectual procrastination toward adapting new, forward-looking concepts and ideas, has often provoked the "blob" label for them. The term was originally derogatorily coined by President Obama's Deputy National Security Advisor for Strategic Communication Ben Rhodes in a 2016 New York Times interview with the David Samuels. ${ }^{7}$ Since then the phrase has become popularized as a label for the attitude of a large segment of the foreign policy elite that lives in a groupthink tower, regurgitating conventional wisdom about precepts of the prevailing international order. ${ }^{8}$

2nd edition. (Oxford: Oxford University Press, 2013); Kori Schake, America vs the West: Can the Liberal World Order Be Preserved? (Melbourne, Australia: Penguin Random House, 2018); Deudney and Ikenberry, 'Liberal World: The Resilient Order,' Foreign Affairs, 97:4 (2018), pp. 16-24; and Paul Staniland, 'Misreading the "Liberal Order": Why We Need New Thinking in American Foreign Policy,' 29 July 2018, https://www.lawfareblog.com/misreading-liberal-order-why-we-need-new-thinkingamerican-foreign-policy, accessed 9 March 2020. 
The "blob" thesis has gained traction in political discourse because it expresses the public's lack of trust in the foreign policy community's predictions and policy recommendations. ${ }^{9}$ This uneasiness has been articulated by some prominent and outspoken academic critics. They allege an uncritical grand strategy consensus among mainstream foreign policy commentators, experts, advisers, and lobbyists in the Beltway. Stephen Walt is one of those critics: he defines the blob as 'individuals and organizations that actively engage on a regular basis with issues of international affairs' ${ }^{10}$ in and outside of US government. Since they are involved in policy advising and policy making, they are part of a dense network that crosses

${ }^{4}$ On the reactions of the US foreign policy community, see Patrick Porter, 'Why US Grand Strategy has not Changed: Power, Habit and the Foreign Policy Establishment,' International Security, 42:4 (2018), pp. 9-46; Patrick Porter, 'A World Imagined: Nostalgia and Liberal Order,' Policy Analysis, 843 (Washington, DC: Cato Institute, June 2018); Dina Smeltz, Karl Friedhoff, Craig Kafura, Joshua Busby et. al., The Foreign Policy Establishment or Donald Trump: Which Better Reflects American Opinion?, Chicago Council on Global Affairs, April 2018, pp. 1-21; Dina Smeltz, Ivo Daalder, Karl Friedhoff, Craig Kafura, and Lily Wojtowicz, America Engaged, American Public Opinion and US Foreign Policy, Chicago Council on Global Affairs, 2018, pp. 2-35; Stephen Chaudoin, Helen V. Milner, and Dustin Tingley, 
partisan lines either through formal shared membership in organizations or informal personal relationships and associations, including friendships, marriage, and kinship. ${ }^{11}$ In government positions like the State Department, DoD, and Congressional staffers, or as members of think tanks, academia, lobby organizations, and the media, these "influentials"12 wield direct and indirect power by shaping foreign policy and policing the boundaries of acceptable policy views.

According to Porter, another critic of the US foreign policy community, one of the main traits of the blob is the habit of self-censorship based on 'obvious, axiomatic choices made from unexamined assumptions, ${ }^{13}$ including the belief in the liberal internationalist ideology

'Down but Not Out: A Liberal International American Foreign Policy,' in Robert Jervis, Robert, Francis J. Gavin, Joshua Rovner, Diane N. Labrosse (eds), Chaos in the Liberal Order: The Trump Presidency and International Politics in the Twenty-First Century (New York: Columbia University Press, 2018), pp. 61-98. Benjamin H. Friedman and Harvey M. Sapolsky, 'Unrestrained: The Politics of America's primacist Foreign Policy,' in A. Trevor Thrall and Benjamin H. Friedman (eds), US Grand Strategy in the 21st Century (London: Routledge, 2018), pp. 220-42 explain some of the reasons for the strong support for the maintenance of the postwar order. For a summary see also Congressional Research Service, 
of primacy, American exceptionalism, and military interventionism according to which 'the United States' hegemonic leadership is axiomatically good for the United States and the world. ${ }^{14}$

The blob thesis of a foreign policy elite intent on upholding the traditional order at all cost is contradicted by the "polarization" thesis. Based on earlier leadership studies ${ }^{15}$ about the breakdown of the US foreign policy consensus, these adherents ${ }^{16}$ argue that in recent decades the divisions about the strategic and tactical outlines of US foreign policy decisionmaking have become more pronounced along ideological and Democratic-Republican partisan lines, a thesis that fits pluralist theory assumptions. ${ }^{17}$

US Role in the World: Background and Issues for Congress. 14 February 2019. https://crsreports.congress.gov/product/pdf/R/R44891.

${ }^{5}$ Mearsheimer, 'Bound to Fail,' p. 7.

6 'Present at the destruction' is a play on US Secretary of State Dean Acheson's 1969 memoir Present at the Creation (New York, W.W. Norton, 1969) describing his role as chief architect of the post-WWII world order.

${ }^{7}$ See David Samuels, 'The aspiring Novelist who became Obama's Foreign-Policy Guru,' New Yorker, 5 May 2016, https://www.nytimes.com/2016/05/08/magazine/the-aspiring- 
Shapiro and Bloch-Elkon, for example, refer to various large quantitative surveys about foreign policy attitudes conducted by the PEW research center, the Chicago Council on Global Affairs, the Council on Foreign Relations, and others, claiming that partisan conflict and polarization between the American public and its leaders reaches back to the 1980s but became increasingly apparent during the G.W. Bush and Obama administrations. ${ }^{18}$ They

novelist-who-became-obamas-foreign policy-guru.html, accessed 9 March 2020. Jeffrey Goldberg, 'The Obama Doctrine,' The Atlantic, April 2016, pp. 70-90, https://www.theatlantic.com/magazine, accessed 9 March 2020. See also Ben Rhodes, The World as it is. A Memoir of the Obama White House (New York: Random House, 2018). 
argue that almost unbridgeable partisan fissures developed between Republican and Democrats, ideological conservatives and liberals. According to defenders of the polarization thesis, Republicans became dominated by realists and neo-conservatives who favored a robust foreign policy of hard power to promote US interests, such as economic sanctions, military pressure, and coalitions of the willing. Democrats, on the other hand, were dominated by liberal internationalists and preferred instead, but not exclusively, soft

${ }^{8}$ Some of the critics like Walt and Porter have extensively used this term to criticize the US foreign policy establishment. See Walt, 'The Hell of Good Intentions,' pp. 112-13 and Porter, 'Why US Grand Strategy has not Changed,' pp. 9 - 46.

${ }^{9}$ See Colin Dueck, 'GOP Foreign Policy Opinion in the Trump Era', Foreign Policy Research Institute (April 23, 2018), https://www.realcleardefense.com/articles/2018/04/23/gop foreign policy opinion in the trump era $113355 . h t m l$, accessed 9 March 2020.

${ }^{10}$ See Walt, The Hell of Good Intentions, pp. 95, 103. For Walt, blob members typically are represented by (transnational) progressives, libertarians affiliated with the Cato Institute, and academic realists. But he treats them less polemical compared to Walter Russell Mead who uses the term "Davoisie" ('In It to Win, 'American Interest, 27 January 2015), or John Bolton, 
power tools, pushing, for example, a values agenda, like democracy and human rights promotion or supporting the responsibility to protect doctrine.

From the viewpoint of 'polarization' advocates, more recent surveys show that splits have emerged within both major parties and among the foreign policy elite on questions about how to deal with terrorism, failed states, immigration and refugees, globalization, international treaties and free trade agreements, alliance burden sharing, and foreign aid. ${ }^{19}$

who called foreign policy elites as "High Minded" in: Surrender is not an Option: Defending America at the United Nations (New York: Threshold, 2007), pp. 441-55. The Alt-right uses comparable labels like "commentariat," "expertocracy," "establishment," "elites," and "globalists," though for derogatory purposes.

${ }^{11}$ Similar C. Wright Mills, The Power Elite (New York: Oxford University Press, 1956). 
Donald Trump was able to tap into anti-globalist resentments and mobilized support from

12 Robert D. Putnam, The Comparative Study of Political Elites (Englewood Cliffs, NJ: Prentice Hall, 1976), p.11.

${ }^{13}$ Porter, 'Why US Grand Strategy has not Changed,' p. 11.

${ }^{14}$ Patrick Porter, 'How the US Foreign Policy Establishment Constrains American Grand Strategy', Policy Brief, International Security (June 8, 2018), pp. 4, 13-14. See also Center for International Security and Governance, International Security Forum, Full Report (Bonn: University of Bonn, 2018), pp. 46-47; and Löfflmann (2019), pp. 7, 13.

${ }^{15}$ Eugene R. Wittkopf, Faces of Internationalism: Public Opinion and Foreign Policy (Durham, NC: Duke University Press, 1990); Ole R. Holsti and James N. Rosenau, 'The Post-Cold War Foreign Policy Beliefs of American Leaders: Persistence or Abatement of Partisan Cleavages?' in Eugene R. Wittkopf (ed), The Future of American Foreign Policy, 2nd edition (New York: St. Martin's Press, 1994), pp. 127-147; Ole R. Holsti, Public Opinion and American Foreign Policy (Ann Arbor: University of Michigan Press, 2004); James A. Stimson, Tides of Consent (Cambridge: Cambridge University Press, 2015); Ole R. Holsti and James N. Rosenau, 'The Structure of Foreign Policy Attitudes among American Leaders,' Journal of Politics 52 (1990), pp. 94-125. 
fringes of the foreign policy community excluded from the mainstream consensus.

${ }^{16}$ See Robert Y. Shapiro and Yaeli Bloch-Elkon, 'Ideological Partisanship and American Public Opinion toward Foreign Policy,' in Morton H. Halperin, Jeffrey Laurenti, Peter Rundlet, and Spencer P. Boyer (eds), Power and Superpower: Global Leadership and Exceptionalism in the 21st Century (New York: Century Foundation Press, 2007), pp. 4968; Nolan McCarty, Keith T. Poole, and Howard Rosenthal, Polarized America: The Dance of Ideology and Unequal Riches (Cambridge, MA: MIT Press, 2006); Barbara Sinclair, Polarization and the Politics of National Policy Making (Norman, OK: University of Oklahoma Press, 2006); Charles A. Kupchan and Peter L. Trubowitz, 'Dead Center: The Demise of Liberal Internationalism in the United States,' International Security, 32:2 (2007), pp.7-44; Joseph Bafumi and Joseph M. Parent, 'International polarity and America's polarization,' International Politics, 49:1 (2012), pp. 1-35; Kenneth A. Schultz, 'Perils of Polarization for US Foreign Policy,' The Washington Quarterly, 40:4 (2017), pp. 7-28; James M. McCormick and Eugene R. Wittkopf, 'Bipartisanship, Partisanship, and Ideology in Congressional-Executive Foreign Policy Relations, 1947-1988,' The Journal of Politics, 52:4 (1990), pp. 1077-1100. Most recent polls confirm a continuation of the polarization trend, see Pew Research Center, Public's 2019 Priorities: Economy, Health Care, Education 
Because both the blob and polarization theses claim to be based on solid evidence, it remains a puzzle how to reconcile their propositions. Can a foreign policy community that is polarized along partisan and ideological lines at the same time share an international order

and Security All Near Top of List, January, 2019, https://www.peoplepress.org/2019/01/24/publics-2019-priorities-economy-health-care-education-and-securityall-near-top-of-list/, accessed 9 March 2020.

${ }^{17}$ See the summary of elite and pluralist theory by Thomas R. Dye and Harmon Zeigler, The Irony of Democracy: An Uncommon Introduction to American Politics 14e (Boston, MA: Cengage, 2009), pp. 10-2, 15-7, and 69.

${ }^{18}$ Robert Y. Shapiro and Yaeli Bloch-Elkon, 'Do the Facts speak for themselves? Partisan Disagreement as a Challenge to Democratic Competence,' Critical Review, 20:1-2 (2008), pp. 115-39.

${ }^{19}$ Robert Shapiro, 'Liberal Internationalism, Public Opinion, and Partisan Conflict in the United States,' in Robert Jervis, Francis J. Gavin, Joshua Rovner, and Diane N. Labrosse (eds), 2018. Chaos in the Liberal Order: The Trump Presidency and International Politics in the Twenty-First Century (New York: Columbia University Press, 2018), pp. 106, 11819. 
consensus? I argue that the answer to this question requires probing beyond quantitative studies and standardized questionnaires. Using an abductive reconstructivist methodology it will become evident that both the blob and polarization theses capture elements of prevailing beliefs among experts but lack a comprehensive explanation of the complexity of US grand strategy imperatives.

After a short description of the sample, method, and evaluation, this article will describe the five fundamental foreign policy "rules for action" identified by the qualitative analysis of 37 in-depth interviews: safeguarding US American global leadership; maintenance of alliances; securing US prosperity; orientation toward US-defined values; and the belief in a US mission. From observable regularities of the interviewees' positions toward those imperatives, four types of foreign policy experts were abductively distinguished: nationalists, realists, pragmatic liberals, ${ }^{20}$ and liberals. The latter three types, labeled here

${ }^{20}$ Pragmatic liberals mix realists and liberal positions. The adjective 'pragmatic' refers to someone who looks for practical solutions making the best of a specific political situation rather than following ideological or value-driven goals. The term is not related to philosophical or methodological pragmatism. Also, the labels "independent" or "centrist" 
under the umbrella category "globalists," are in favor of upholding the postwar international order as a win-win arrangement. They oppose the efforts of Trump nationalists to tear down this order in favor of a transactional and unilateral zero-sum relationship of the US with friends and foes. But realists, pragmatic liberals, and liberals are unsure of how to explain and respond to Trump's nationalism beyond a defensive or wishful hope to save the vestiges of an US-centric international order.

The summary will draw theoretical and methodological conclusions from these empirical findings and reveal, that the blob thesis, while correctly capturing a pro-international order consensus among globalists, neglects deeper divisions that divide realists, pragmatic liberals, and liberal's interpretation of how to achieve international order goals. On the other hand, the polarization thesis, while correctly describing a partisan and ideological divide among the foreign policy community, ignores the anti-nationalist consensus of the globalists. ${ }^{21}$

were avoided because they are associated with voting patterns or a partisan Left-Right continuum.

${ }^{21}$ On the anti-Trump consensus, see Joshua W. Busby and Jonathan Monten, 'Has Liberal Internationalism Been Trumped?' in Robert Jervis, Robert, Francis J. Gavin, Joshua Rovner, Diane N. Labrosse (eds), Chaos in the Liberal Order: The Trump Presidency and 
As this study demonstrates, richer and more contemporary insights into the divisions and consensus of foreign policy experts' grand strategy perceptions can be gained by applying qualitative methods.

\section{Sample}

This study is based on the assumption that foreign policy experts share a set of ingrained beliefs about the role, function, mission, and obligations of their country in international affairs. ${ }^{22}$ It hypothesizes that expert opinion precedes public opinion and influences it in multiple ways, particularly through the media and through policy advising via think tanks. ${ }^{23}$

International Politics in the Twenty-First Century (New York: Columbia University Press, 2018), pp. 49-60.

${ }^{22}$ Anja Dalgaard-Nielsen, Germany, Pacifism and Peace Enforcement (Manchester: Manchester University Press, 2006), p. 21.

${ }^{23}$ Gabriel A. Almond, The American People and Foreign Policy (New York: Harcourt, Brace \& Co, 1950); Anthony Giddens, The Constitution of Society (Cambridge, MA: 
In brokerage-type party systems with strong special interest groups, think tanks formulate policies and promote partisan ideological objectives to members of Congress, the executive, mass media, and the public. ${ }^{24}$ Think tanks are in constant competition to have their specific interpretations of the advancement of national interests accepted as dominant and to provide definitions of what should be considered "us" versus "them," what is considered legal, useful, and desirable for a society, and its special mission in international affairs. ${ }^{25}$

For this reason, this study focused on interviewing members from prominent Washington, DC think tanks in addition to selected congressional staffers, diplomats, academics, and media opinion makers with high reputation and expertise. Of the 111 foreign policy experts

Polity Press, 1984); James Allen Smith, The Idea Brokers: Think Tanks and the Rise of the new Policy Elite (New York: Free Press, 1991.

${ }^{24}$ Lawrence R. Jacobs and Benjamin I. Page, 'Who Influences US Foreign Policy?' American Political Science Review, 99:1 (2005), pp. 107-23.

${ }^{25}$ Alexandra Guisinger and Elizabeth Saunders, 'Mapping the Boundaries of Elite Cues: How Elites Shape Mass Opinion Across International Issues,' International Studies Quarterly, 61:2 (2017): pp. 425-41; and Stephen G. Walker, Role Theory and Foreign Policy Analysis (Durham, NC: Duke University Press, 1987). 
contacted through a mix of convenience and snowball-sampling methods using funds and networks from the author's home university in Michigan, 22 individuals declined to participate for a variety of reasons and 52 did not respond to phone messages or to emailed interview requests ${ }^{26}$. Of the 37 experts ( 33 percent) who agreed to an interview, 25 were met face-to-face and 12 questioned by phone. ${ }^{27}$ The average interview lasted 55 minutes. Because the overall population of foreign policy experts cannot be clearly determined, the sample selection was not representative. Nevertheless, respondents' occupational functions, party affiliation, age, and sex were considered to ensure that the sample captured a diverse spectrum of foreign policy experts, ${ }^{28}$ thereby fulfilling the saturation criteria recommended

${ }^{26}$ Originally it was planned to conduct about 75 interviews but a shortage of funds and research time limited the sample. A larger sample probably would have allowed to map further nuances within each typology - as between libertarian realists, neo-conservatives, and so forth.

${ }^{27}$ From a quantitative perspective, the study's sample size might appear small. However, compared with other qualitative interview studies it is still slightly above average, see Mario Luis Small, 'How Many Cases do I Need?' Ethnography, 10:1 (2009), pp. 5-38; and Mark Mason, 'Sample Size and Saturation in PhD Studies Using Qualitative Interviews,' Forum 
for qualitative sampling. ${ }^{29}$

Most respondents came from 18 well-known foreign policy DC think tanks, among them six conservative, six centrist, and six liberal or progressive institutions. ${ }^{30}$ Five think tanks were

Qualitative Social Research, 11:3 (2010), http://nbn-resolving.de/urn:nbn:de:0114fqs 100387.

${ }^{28}$ For comparative reasons, the sample included seven non-US or dual citizens (cases 4, 6, $8,11,15,17$, and 19) whose perceptions overlapped with that the other experts, adding confidence about the consistency of the findings.

${ }^{29}$ Janice M. Morse, 'Designing funded qualitative research,' in Norman K. Denzin and Yvonna S. Lincoln (eds), Handbook of Qualitative Research (Thousand Oaks: Sage, 1994), pp. 22035; and Matthew B. Miles, A. Michael Huberman, and Johnny Saldaña, Qualitative Data Analysis 3e (London: Sage, 2013).

30 This compares with a 'recent study by the progressive media watchdog FAIR of the most cited think tanks [which] found [that] $48 \%$ are centrist, 31 percent are conservative, and 21 percent are left-center or progressive,' see Louis Schubert, Thomas R. Dye and Harmon Zeigler. The Irony of Democracy: An Uncommon Introduction to American Politics, $17^{\text {th }}$ edition (Boston, MA: Cengage, 2016), p.72. 
foreign-funded. In addition, a private think tank and a law firm involved with think tank advising were represented in this category. Thirteen of the 26 think tank interviewees were directors or presidents of their organizations. Because of the prevalent "revolving door" job rotating mechanism and the tightly-knit and overlapping networks that characterize the DC foreign policy elites, many US respondents previously held jobs in federal and state positions, academia, the legislative branch, military, foundations, NGOs, other think tanks, private enterprises, law, and investment firms. For this reason, the sample also included five university academics affiliated with foreign policy research or think tank institutions as well as a former State Department Secretary, a diplomat, three Senate staffers, one staffer from the House of Representatives, and a research director from the Library of Congress.

Eighty-four percent of the 37 respondents were White males, which is typical for the current race and sex distribution of the expert community in DC. The participants' average age was 54 and ranged from 32 to 91 years. Forty-six percent of the interviewed persons held a $\mathrm{PhD}$ or JD, and many respondents had degrees from Ivy League or similar institutions in the United States or England, indicating the elite educational status of the sample. ${ }^{31}$ Sixty

31 Joshua W. Busby and Jonathan Monten, 'Without Heirs? Assessing the Decline of Establishment Internationalism in US Foreign Policy,' Perspectives on Politics, 6:3 (2008), 
percent of the experts were nonpartisan or their party affiliation was unknown. Among the 15 persons with a known party affiliation, nine were Republican Party members and six were Democrats. From the variation of responses, it can be deduced that the sample reaches across ideological and political lines from progressive left to liberal, centrist, conservative, and nationalist positions.

\section{Reconstructivist Methodology and Evaluation}

Analyzing these 37 interviews required making assumptions about the conceptualization and empirical operationalization of grand strategy imperatives that guide policy actors in their

interpretation and enactment of foreign policy. ${ }^{32}$ In this study a reconstructivist approach ${ }^{33}$

pp. $451-72$ found that between $42 \%$ and $46 \%$ of top executive branch officials and the heads of foreign policy committees in Congress during and after the Cold War came from Ivy League backgrounds. 
was applied combining ontological, epistemological, and methodological premises from hermeneutics,${ }^{34}$ grounded theory, ${ }^{35}$ and philosophical pragmatism's "belief is a rule for action." ${ }^{36}$ This approach shares a similar focus on the "intersubjective construction of reality"37 by foreign policy actors as the theories of political and strategic culture and related concepts like cognitive mapping, ${ }^{38}$ operational mindset/code, ${ }^{39}$ framing, or image theory. I preferred the reconstructivist methodology for this project because its "rules for action" concept pays attention to the interaction between political structures and human agency in the form of coagulated shared ideas, norms, and interests.

${ }^{32}$ Nina Silove, 'Beyond the Buzzword: The Three Meanings of "Grand Strategy,"' Security Studies, 27:1 (2018), pp. 39-41.

${ }^{33}$ The reconstructivist IR approach attempts to understand 'the fundamental script of the role and identity of ... foreign policy' in the views of its actors, see Ulrich Roos, 'Beliefs and Loyalties in World Politics: A Pragmatic Liberal Framework for Analysis,' in Gunther Hellmann and Knud E. Jørgensen (eds), Theorizing Foreign Policy in a Globalized World (London: Palgrave Macmillan, 2015), p. 180. See also Ulrich Franke and Ulrich Roos, 'Actor, Structure, Process: Transcending the State Personhood Debate by Means of a Pragmatic Liberal Ontological Model for International Relations Theory', Review of 
In this study, rules for action are defined as shared sets of beliefs of actors about grand strategy imperatives in a specific foreign policy "structure of corporate practice" 40 that has been formed over a long time ${ }^{41}$ and adheres to basic principles of cognitive consistency and legitimacy. ${ }^{42}$ Rules for action are the complex result of internalized social and cultural

International Studies, 36 (2010), pp. 1057-77; Ulrich Franke and Gunter Hellmann, 'American Pragmatism in Foreign Policy Analysis,' in Oxford Research Encyclopedia of Politics (2017), pp. 1-16, doi.org/10.1093/acrefore/9780190228637.013.356. 
learning such as collective memories, traditions, and dominant societal norms. In addition, they are influenced by shared experiences of historical events, lessons learned from political decisions and their fall-out, and future expectations.

A reconstructive analysis of interview responses, speech acts, or documents allows the trained observer to distill prevalent rules for action contained in these utterances. In qualitative analysis the focus is therefore not on testing positivist assumptions about expert

${ }^{34}$ Ulrich Oevermann, 'Die Methode der Fallrekonstruktion in der Grundlagenforschung sowie der klinischen und pädagogischen Praxis,' in Klaus Kraimer (ed.), Die Fallrekonstruktion. Sinnverstehen in der sozialwissenschaftlichen Forschung (Frankfurt/Main: Suhrkamp, 2000), pp. 138-56.

${ }^{35}$ Anselm S. Strauss, Qualitative Analysis for Social Scientists (Cambridge: Cambridge University Press, 1987); Barney G. Glaser, Basics of Grounded Theory Analysis (Mill Valley, CA: Sociology Press, 1992).

${ }^{36}$ Charles Sanders Peirce, 'How to make our ideas clear,' in Nathan Houser and Christian J.W. Kloesel (eds), The Essential Peirce: Selected Philosophical Writings 1, 1867-1893 (Bloomington: Indiana University Press, 1992/1878), p. 130. This does not imply that beliefs are identical with action but points out how beliefs are operationalized into imperatives that 
beliefs using theoretical models of rules for action (which are not yet existing for this specific situation) and then finding evidence that fits with these predictions. Instead, the goal is to extract evidence in form of patterns through iterative procedures of coding and analysis. Through this process generic knowledge and new conclusions are drawn (see also above section 'Sample and Evaluation'). This way the actors' (not the researchers') understanding of fundamental rules for action and related typologies are reconstructed. ${ }^{43}$ By creating new theses open to empirical falsification and revision in the future, this study is "crossing paradigmatic borderlines," 44 helping us to develop a deeper and richer explanation of elite beliefs. $^{45}$

can be achieved by specific actions. While imperatives are collectively shared the pathway, means, and intentions toward achieving them allows for variants of action.

37 Mathias Albert and Stephan Stetter, 'Actorhood in World Politics: The Dialectics of Agency/Structure within the World Polity,' in Hellmann and Jørgensen, 'Theorizing Foreign Policy in a Globalized World,' pp. 81-100.

${ }^{38}$ Judith Goldstein and Robert O. Keohane (eds), Ideas and Foreign Policy (Ithaca and London, Cornell UP, 1993), p. 16. 
The evaluation of the audiotaped interviews using MAXQDA qualitative software followed the flexible coding approach, ${ }^{46}$ starting out with the creation of summary memos and indexing the answers to questions about how respondents described their foreign policy beliefs, lessons learned, challenges ahead, future foreign policy priorities, etc. Then 'summative, salient, essence-capturing, and/or evocative attributes' ${ }^{\prime 4}$ of responses were thematically coded into categories like leadership, prosperity, alliances, values, US mission, etc. ${ }^{48}$ The latter codes were then further sub-categorized and reordered. The iterative process

39 Benjamin H. Friedman and Justin Logan, 'Why Washington Doesn't Debate Grand Strategy,' Strategic Studies Quarterly, 10:4 (2016), p. 15.

${ }^{40}$ Roos, 'Beliefs and Loyalties in World Politics,' p.180.

41 The causes and processes that lead to the long-term formation and change of rules for action are not a topic of this study. They have been addressed in other contexts, see footnotes 35 and 47. 
of (re)coding, comparing, ordering, linking, and classifying was strengthened by triangulating the qualitative findings with a quantitative comparative evaluation of sociodemographic characteristics of the respondents to test the credibility, applicability, and consistency of the sample, coding, and analytical evaluation.

Unlike quantitative surveys using pre-set categories and standardized questionnaires developed by the researcher, the reconstruction of rules for action and the actor typology in this study was derived from how experts represented their positions in the open-ended interviews. The abductive results are actor-centric, allowing unique and highly reliable

${ }^{42}$ Similar Philipp E. Converse, 'The Nature of Belief Systems in Mass Publics,' in David E. Apter (ed.), Ideology and Discontent (New York: The Free Press, 1964), pp. 206-61; and Ole R. Holsti, The "Operation Code" as an Approach to the Analysis of Belief Systems: Final Report to the National Science Foundation. (Durham, NC: Duke University, 1977).

${ }^{43}$ Alexander L. George and Andrew Bennett. Case Studies and Theory Development in the Social Sciences (Cambridge, MA: MIT Press, 2005), p.7.

44 Peter Katzenstein and Rudra Sil, 'Eclectic Theorizing in the Study and Practice of International Relations,' in Christian Reus-Smit and Duncan Snidal (eds), The Oxford Handbook of International Relations (Oxford: Oxford University Press, 2008), pp. 109 -30. 
patterns of thinking emerge from the actors' views, thereby improving our insights into the complexities of their reasonings. That way elite interviews become 'a tool to tap into political [actor's] constructs that may otherwise be difficult to examine'49 by standardized survey questions.

${ }^{45}$ For examples about the application of reconstructive foreign policy analysis, see Ulrich Roos and Charlotte Rungius, 'Neue Macht, neue Mächte - gute Gründe? Rekonstruktion einer außenpolitischen Diskursoffensive in Deutschland,' Zeitschrift für Außen- und Sicherheitspolitik, 9 (2016), pp. 39-78; Ulrich Roos, Deutsche Außenpolitik. Eine Rekonstruktion der grundlegenden Handlungsregeln (Wiesbaden: Springer VS Verlag für Sozialwissenschaften, 2010); Ulrich Franke and Ulrich Roos, 'Einleitung: Zu den Begriffen "Weltpolitik" und "Rekonstruktion",' in Ulrich Franke and Ulrich Roos (eds), Rekonstruktive Methoden der Weltpolitikforschung (Baden-Baden: Nomos, 2013), pp. 729; Hermann Kurthen and Helmar Schöne, 'Aussenpolitische Handlungsregeln in Deutschland. Ergebnisse aus Experteninterviews während der Libyenkrise 2011,' Zeitschrift fur Aussen- und Sicherheitspolitik, 11:1 (2018), pp. 39-64; Hermann Kurthen (in press), 'German Foreign Policy Rules for Action during the 2011 Libya Crisis,' German Politics and Society. 


\section{Foreign Policy Rules for Action}

This section describes the five foreign policy rules for action and the different interpretation of their meaning and application by four actor types, both abductively distilled from the reconstructive analysis of the 37 interviews. The actor types are labeled as nationalists versus realists, pragmatic liberals, and liberals. As mentioned earlier, I also refer to the latter three

${ }^{46}$ Nicole Deterding and Mary C. Waters, 'Flexible Coding of In-depth Interviews: A Twenty-First-Century Approach,' Sociological Method and Research, (2018), pp.1-32, https://doi.org/10.1177/0049124118799377, accessed 9 March 2020.

47 Johnny Saldaña, The Coding Manual for Qualitative Researchers (London: Sage, 2009), p. 7 .

${ }^{48}$ See similar recommendations by Jochen Gläser and Grit Laudel, Experteninterviews und qualitative Inhaltsanalyse als Instrumente rekonstruierender Untersuchungen (Wiesbaden: VS Verlag für Sozialwissenschaften, 2004).

${ }^{49}$ Glenn Beamer. 2002. 'Elite Interviews and State Politics Research.' State Politics \& Policy Quarterly, 2:1 (2002), p. 87. See also Iddo Tavory and Stefan Timmermans, 2012. Abductive 
groups with the umbrella term 'globalists' because they believe in the maintenance of the postwar international order in contrast to the nationalists.

The typology reaffirms the existence of relatively stable and consistent but also constrained ideological worldviews of US foreign policy experts. ${ }^{50}$ While the typology labels used here

Analysis: Theorizing Qualitative Research (Chicago, IL: University of Chicago Press, 2012).

${ }^{50}$ Holsti, 'Public Opinion and American Foreign Policy,' p. 127, 192; Wittkopf,' Faces of Internationalism;' William O. Chittick, Keith R. Billingsley, and Rick Travis, 'A Three 
are nominally similar to previous IR classification schemes, ${ }^{51}$ the content is different. It

Dimensional Model of American Foreign Policy Beliefs,' International Studies Quarterly, 39 (1995), pp. 313-31; Jon Hurwitz and Mark Peffley, 'How Are Foreign Policy Attitudes Structured? A Hierarchical Model,' American Political Science Review, 81 (1987), pp. 10991120; Virginia A. Chanley, 'US Public Views of International Involvement from 1964 to 1993,' Journal of Conflict Resolution, 43 (1999), pp. 23-44; Ulf Bjereld Ann-Marie Ekengren, 'Foreign Policy Dimensions: A Comparison Between the United States and Sweden,' International Studies Quarterly, 43:3 (1999), pp. 503-18; and Benjamin I. Page and Robert Y. Shapiro, The Rational Public: Fifty Years of Trends in Americans' Policy Preferences (Chicago, IL: University of Chicago Press, 1992).

${ }^{51}$ Large quantitative, survey-based typologies discussed in the US literature typically range from left liberal internationalists to conservative realists and unilateral nationalist positions, although the political science literature has never come to a conclusive agreement about how many and which labels to use for describing the full spectrum of empirical beliefs among foreign policy actors in the US at a given moment. See Holsti and Rosenau, 'The Structure of Foreign Policy Attitudes among American Leaders;' Shoon K. Murray, Anchors Against Change: American Opinion Leaders'Beliefs after the Cold War (Ann Arbor, MI: University 
differs because the typology used here was generated through qualitative reconstruction, not through quantitative deduction based on standardized survey questions; additionally, the typology used in this study reflects empirical patterns of beliefs extracted from interviews in Fall 2017.

Nevertheless, the typology presented here should not be understood as reified categories, given the limited sample size and the idiosyncratic and ambiguous nature of individual actor's assessments of complex foreign policy issues. In other words, the typology presented here approximates patterns of rules for action that existed among the larger US foreign policy expert community at the time of the interviews. Table 1 summarizes the five most salient foreign policy rules for action mentioned by all interviewed experts and these imperatives' different interpretation by expert type.

of Michigan Press, 1996); Brian C. Rathbun, 'Does One Right Make a Realist? Conservatism, Neoconservatism, and Isolationism in the Foreign Policy Ideology of American Elites,' Political Science Quarterly, $123: 2$ (2008), pp. 271-99; Daniel W. Drezner, 'The Realist Tradition in American Public Opinion,' Perspectives on Politics, 6:1 (2008), pp. 51-70; John T. Rourke and Mark A. Boyer, International Politics on the World Stage, $8^{\text {th }}$ edition (New York: McGraw-Hill, 2010). 
$<$ INSERT TABLE 1 HERE $>$

\subsection{Global leadership}

As mentioned, rules for action work like frames through which decision-makers, experts, and other relevant actors reflect their country's global role, its ultimate goals, and values for which it stands and then use them as guidance to make judgments about present and future action. In that sense, rules for action become actor imperatives.

The most important rule literally stated by respondents was "US global leadership." It was usually described in the interviews as maintaining US military and diplomatic presence on all continents to guarantee a US dominated global order and peace. Many experts mentioned goals like protection of the US homeland against nuclear war and defense of its borders, institutions, and citizens against crime, terrorism, cyber-attacks, and illegal immigration. ${ }^{52}$

\footnotetext{
52 The prevention of the spread of WMD's was not mentioned in the interviews as a separate imperative but subsumed under leadership/primacy/security, a finding that differs from
} 
However, nationalists, realists, pragmatic liberals, and liberals differed in the terminology used, the priorities, and methods to achieve this rule for action.

While many liberal experts favored using the term "leadership," smaller numbers of respondents used "liberal hegemony", or the word "primacy," common in the IR literature and a favorite among realists in the sample. ${ }^{53} \mathrm{~A}$ diplomat provided the following definition of leadership:

Our US bipartisan fundamental principle has been to create, manage, maintain, protect, and nurture a global political, economic, and security order in which we as a country can be secure, thrive, and advance economically and politically. .... Building a global

Porter's definition of US grand strategy, see Patrick Porter, 'Why America's Grand Strategy has not Changed,' International Security, 42:4 (2018), p.9.

${ }^{53}$ Friedman and Logan claim that 'the vast majority of US foreign policymakers are devotees of primacy, a grand strategy that sees global US military exertions—alliances, foreign bases, patrols, military training, regular wars, and continual airstrikes - as the only guarantee of national security, global stability, and free trade.' See Friedman and Logan, 'Why Washington Doesn't Debate Grand Strategy,' p. 14. 
architecture, a political, security and economic architecture, within which we [the United States] could prosper, maintain our security, and pursue our interests. This is for me one of the most fundamental US bipartisan principles.... We [the United States] see ourselves as the architect, manager, and protector of that architecture (Case 28/Liberal). ${ }^{54}$

As mentioned, "primacy" covered similar dimensions as "global leadership" but with a focus on superiority, domination, and reigning-in rising powers or adversaries, a point that is also recognized in the literature. ${ }^{55}$ In the interviews, nationalists tended to be "hyperrealists" considering "primacy" a "natural" byproduct of a nation combining its superpower with its interests. Realists and many pragmatic liberals argued that the US seeks to promote and

${ }^{54}$ In the cited transcripts the symbol "..." denotes that parts of a transcript have been omitted for the sake of brevity, while [...Text...] indicates an addition by the author to make the citation grammatically correct or its contextual reference better understandable for the reader.

55 See, for example, Stephen G. Brooks and William C. Wohlforth, 'American Primacy in Perspective,' Foreign Affairs, 81:4 (2002), pp. 20-33; Thrall and Friedman, US Grand Strategy in the 21st Century; and Friedman and Sapolsky, 'Unrestrained.' 
protect US military and political interests and assets abroad and to 'maintain the dollar as the major currency, maintain American global economic dominance, and control of the trade lines' (Case 19) while carefully avoiding too much and too little foreign intervention to retain its legitimate global authority.

A few in the liberal group characterized the United States as a "hegemonic" leader, a term that was avoided on Capitol Hill and by most think tank respondents because it is seen as pejorative. But even if this term was not used, the goals of US foreign policy mirror its dominance in world politics. For example, a respondent pointed out that the United States follows a geopolitical strategy of forward continental defense with the goal of 'preventing regional hegemons on either side of the Eurasian landmass emerging. Preventing particularly Germany and Japan from becoming nuclear powers by providing security for them' (Case 17/Realist). Or in the words of another realist, the United States does not want to 'let major powers grab and dominate pieces of the planet' (Case 33/Realist).

Interviewees also mentioned the US leadership task 'to maintain or expand American spheres of influence' by stabilizing or replacing regimes by those more willing to cooperate, and, at the same time, by containing adversaries. A realist referred in the interview to the IR scholar John Ikenberry, who supposedly described the 
genius of the American system ... that you use your power not to make people want to do what you do you, but you make it so attractive or so good for them that they want to do it at their free will (Case 10/Realist).

Members of the liberal group less openly displayed such shrewd foreign policy views and, instead, stressed the principle of peacefully engaging adversaries and competitors through diplomacy and other soft power tools to promote a stable rules-based order. Liberals criticized a tendency toward militarization among hard power realists to 'take out the hammer when you reach for the toolbox' (Case 15/Liberal). But liberals were not averse to the idea of intervention abroad to

'fix' [countries] with [our allies]. It is somewhat naïve but it certainly influences how we talk about foreign policy [in] any corner of the world. You will find people who are arguing for US involvement. Whether it is from the development angle, trade, or military peacekeeping/peacebuilding.... the notion of [US involvement] is still the normal conversation going on in Congress (Case 12/Liberal).

Among all respondents, a consensus existed about the need for US global leadership/primacy. However, globalists and nationalists strongly differ on the means achieving this goal, which supports the blob thesis. For example, globalists criticize the 
nationalists' transactional zero-sum attitude of 'might makes right' which in their eyes rejects the self-imposed obligations of benign and legitimate US global leadership, which requires that the US should respect itself the rules of the international order it helped to establish. On the other hand, ideological and partisan differences also existed between realists, pragmatic liberals, and liberals about the precise meaning of leadership and how to implement it within the framework of the international order. This finding supports the polarization thesis. For example, while not being opposed to the use of soft power, many realists expressed skeptical views about its effectiveness. For them the maintenance of military superiority was a legitimate means to play out US advantages in a rules-based but US dominated order. Liberals, on the other hand, prioritize soft power and leadership through engagement strategies, whereas pragmatic liberals typically favored a mix of hard and soft power, like 'a commitment to peaceful settlement of international disputes backed by the use of force when necessary' (Case 27/Pragmatic Liberal).

\subsection{Alliances}

Another rule for action that all respondents shared in the interviews was the imperative to uphold a system of "alliances" for the good of the United States and for its allies, in particular containing so-called 'bad guys' and providing order and stability through the use of 
international institutions, laws, and treaties. ${ }^{56}$ No matter what the actor type, there was a consensus that the NATO alliance and "fair" burden-sharing are central pillars for historical, military, political, economic, and cultural reasons:

In the [US] foreign policy elites and the military defense elites, for them NATO is still very important, MORE important than sometimes for the Europeans. There was not much done with regard to NATO in the last 25 years. But for the US elites it is still a very important institution (Case 19/Pragmatic Liberal).

But sharp disagreements existed among respondents about the meaning and importance of alliances and multilateralism. Nationalists, while rejecting the label of being isolationists (Case 35/Nationalist), were most outspoken against giving 'too much legal, cultural, political power to globalists, the UN' (Case 1/Nationalist), international law, and 'multilateral agreements' (Case 36/Nationalist), fearing a loss of US national sovereignty to exercise foreign policy in uni- or bilateral fashion when opportune. Realists, pragmatic liberals, and liberals, on the other hand, recognized the benefits of international cooperation in enhancing

\footnotetext{
${ }^{56}$ In the literature this instrumental interpretation of alliances and multilateralism is often associated with liberal institutionalism, see Mearsheimer, 'Bound to Fail,' p. 23.
} 
US national security and global stability. But realists harbored a more instrumental and liberals a more cooperative interpretation of collective security and alliances with democratic capitalist states with similar values.

For realists the US national security and stability of the order had precedence. If necessary, they would resort to coalitions of the willing. International institutions (like the UN) and international law and treaties (like the Paris Climate Accord) were often judged skeptically, even negatively, either as instruments of weaker powers wanting to constrain the US freedom of action or as institutions incapable of fulfilling their goals. Even some liberals agreed that changes were needed, like the following expert:

We do need to develop a strategy of how the United States wants to approach that [goal of renewing international system]. We need to develop it in consultation with all of our partners on the [UN] Security Council, even those who are rivals in many instances. We need to speak more frankly with each other. ... All nations need to be consulted in developing a plan to renew the international system (Case 22/Liberal).

Except for the centrality of NATO as a pillar of US military and political global leadership, the interpretation of who should be considered an ally, when to go it alone, and what multilateralism signifies was discussed very differently. Realists, pragmatic liberals, and 
liberals shared a consensus in maintaining a system of alliances because it benefits the US and rejected the nationalist's adversarial or transactional relationship with traditional US allies and their emphasis on sovereignty. But the interpretation of how to practice this rule for action is controversial among realists, pragmatic liberals, and liberals. This illustrates again that both, the blob and polarization theses, capture elements of prevailing beliefs among experts, but they lack a comprehensive explanation of the different levels of agreement and disagreements surrounding the international order paradigm.

\subsection{Prosperity}

One more rule for action mentioned by all respondents was the "prosperity"57 agenda. It concerns the promotion of private entrepreneurship, market capitalism, and related institutions enhancing US prosperity through its global spread. Again, differences appear when respondents discuss what this means and how this imperative should be implemented.

The nationalists believed that 'free trade is not working for us' (Case 36/Nationalist) and had a transactional cost-benefit view about how to regain economic primacy and freedom of

\footnotetext{
57 What I call the prosperity agenda is in the literature often associated with the economic interdependence theory, Ibid., p.23.
} 
action through protectionist measures and the abolishment of supranational regulations, constraining trade agreements, and related institutions (Case 1/Nationalist). In contrast, realists, pragmatic liberals, and liberals all stressed the domestic and international benefits of an

open international economic system based on free trade ... [since] ... there are multiple national interests, there is not just one. Internationally, we have an interest in strengthening the rules-based international order, and not seeing a return to spheres of influence worlds or a world divided into trading blocs again and things like that. We have an interest in an integrated and open international economic system because it generates economic growth and employment in the United States .... We have an interest in bolstering our own domestic economy, which, at the end of the day, is the engine of our national power. (Case 32/Pragmatic Liberal).

Another pragmatic liberal underscored the objective of strengthening the global position of the United States as a trading nation interested in free access to markets, an opinion that was shared by many other realists and pragmatic liberals:

The goals are the maintenance or extension of the market economy, and of the predominance or considerable share of these markets for the United States, for our banks 
and production companies particularly. More recently, for our electronics and Internet companies. But obviously the maintenance of a very, very large market share in the global market is a goal (Case 14/Pragmatic Liberal).

While pragmatic liberals and realists more often focused on the advantages of free trade for US business, liberals frequently pointed out the role of free trade in contributing to global stability, peace, development, pro-Western attitudes, and the spread of individual liberties, even democratization. This interpretation reflects major tenets of the "Economic or Capitalist Peace" 58 theory. A few liberals also mentioned foreign aid, fair global trade, or the upholding of standards like the 'right to work, fair labor compensation, and work under conditions that are humane and safe' (Case 22/Liberal) as aspects of their interpretation of the prosperity agenda. This is not surprising because liberals are more likely affiliated with the Democratic Party, which has a strong affiliation with the more regulation-oriented unions.

Overall, there was a consensus among realists, pragmatic liberals, and liberals that free trade

${ }^{58}$ See Gerald Schneider, 'Capitalist Peace Theory: A Critical Appraisal,' in William R. Thompson (ed.), The Oxford Research Encyclopedia of Politics (Oxford: Oxford University Press, 2017), https://doi.org/10.1093/acrefore/9780190228637.013.314. 
and market capitalism a.k.a. globalization is intrinsically good since they have benefited the United States but also the world economy. These experts also were adamant in their condemnation of what they saw as the nationalist's anti-globalist rhetoric, anti-free trade protectionism, transactionalism, and unwillingness to comprehend global prosperity as a win-win proposal. Thus, the observed views of realists, pragmatic liberals, and liberals versus the nationalist corroborate the blob thesis. However, the different attitudes between realists, pragmatic liberals, and liberals about the implementation of this rule for action, such as the degree of regulation, the purposes of trade compacts, and its main beneficiaries, are in support of the polarization thesis.

\subsection{Values}

"Values" and what I call in the next section "mission" agenda are ideational imperatives that help to legitimize the US American foreign policy actions. Here the difference between nationalists and globalists is the emphasis on how to define, protect, advance, and spread various aspects of democracy, individual liberties, and the American way of life. While nationalists do not deny the existence of 'universal' American values, they express a more laissez faire attitude about the use of values as a tool of foreign policy. A nationalist pointed out that under Trump 
we are not going to hector them [allies like Egypt and Saudi Arabia] on human rights issues, ... we are turning away from BOTH Bush and Obama (Case 36/Nationalist). Another nationalist deflected the question about his understanding of values in foreign policy by stating: We want 'America First', we want to strengthen the United States [to...] keep things safe, secure, prosperous, and just' for the United States (Case 1/Nationalist).

Among realists, pragmatic liberals, and liberals, on the other hand, a consensus existed that values are part of the moral compass of US foreign policy, though their meaning and implementation differed. Equal numbers of experts, among them many liberals and pragmatic liberals, identified values with a moral commitment to promote human rights, human dignity, and tolerance, or a responsibility to protect (R2P). Others defined it as the support for democratic governance, rule of law, or the division of power, including a system of checks and balances. A third, but smaller group of mostly realists, focused on fostering the practice of individual rights and civil liberties, the ability to pursue life, liberty, happiness, and various other freedom rights regarding economic activity, the free exchange of ideas, innovation, diversity of lifestyles, or making sure that foreign policy is geared toward protecting humans "from" something, like corruption, totalitarian ideologies, and autocratic state incursion. 
While not denying that values should be a complement of foreign policy for 'strategic reasons' (Case 13/Realist) or undergird the US 'security architecture' (Case 16/Realist), many realists expressed skepticism about the active promotion of values through military or political intervention, such as the following realist interviewee:

For instance, in dealing with Russia, we should not be concerned about the way Russia is ruled. I do not like or admire Vladimir Putin, but I am more interested in making sure that we do not find ourselves fighting the Russians. When has Russia been democratic? The same goes... I worry about China as a global superpower, not about how China is ruled within China. I do not think it should be the role of the United States to intervene around the world and promote our values (Case 3/Realist).

Typical of pragmatic liberals was the comment of a think tank member (Case 27) who approvingly observed that the prominent human rights agenda is a normative or aspirational ideal which 'may slide up and down' in actual policy preference and practice among different administrations.

In contrast, respondents labeled as liberals and a few pragmatic liberals were more inclined toward promoting values abroad, arguing, for example, that spreading values like democracy would help to avoid 'wars, bloodshed, and conflict' because democracies 'do not go to war 
with each other' (Case 18/Pragmatic Liberal), or it would prevent 'bad things from happening around the world' (Case 25/Liberal). They also pointed out that the United States is not 'imposing our values on the rest of the world' (Case 9/Liberal) but 'speaking for humanity overall' (Case 6/Liberal). These interpretations align with the Democratic Peace Theory. ${ }^{59}$

Several experts commented on the moralistic character of the US values agenda as 'proceeding from a set of almost Protestant puritanical assumptions about the sinfulness of the world' (Case 16/Realist), or 'making the world in its [the United States] image' (Case 26/Realist), or designed to 'morally inspire' Americans (Case 37/Realist) since referring to national interest alone would be considered insufficient to motivate the American public to broadly support US foreign policy. A few interviewees criticized the 'idealism' of the values agenda (Case 15/Liberal) or pointed out the hypocrisy of selectively promoting democracy and liberal values, as in the case of Europe, where the United States 'rules by rules but in

59 See Patrick A. Mello, 'Democratic Peace Theory,' in Paul Joseph (ed.), The SAGE Encyclopedia of War: Social Science Perspectives (Thousand Oaks: Sage, 2016), pp. 47276; and Zeev Maoz and Bruce Russett 1993, 'Normative and Structural Causes of Democratic Peace, 1946-1986,' American Political Science Review, 87:3 (1993), pp. 62438. 
Latin America [acts] mostly imperial' (Case 17/Realist). ${ }^{60}$

Altogether, all experts in this study agreed that values play a role in foreign policy, beyond that generic agreement, fissures between expert types were again visible. Nationalists had the most aloof opinion and considered values a feeble moral imperative that did not contribute much to US power and interests. Realists, pragmatic liberals, and liberals disagreed with this pessimistic attitude maintaining that values should guide US foreign policy and, therefore, criticized Trump nationalists for their neglect, if not violation, of values by dealing with odious regimes and leaders - a finding that supports the blob thesis. At the same time, globalists differed in their interpretation of the meaning, ranking and implementation of the values agenda, a result that goes along with the polarization thesis.

\subsection{American mission}

The multifaceted belief in a US mission was the fifth rule for action shared by all experts. Both the values and the mission imperatives can be considered morally loaded ideological

${ }^{60}$ Seven respondents - representing different globalist expert types - self-critically remarked that the actual implementation of values in the United States itself was far from consistent (Cases 10, 14, 18, 26, 28, 33, and 37). 
capstones legitimizing US global leadership, alliances, and prosperity goals. For nationalists, the mission is a patriotic imperative to restore and maintain the presumed inherent "greatness" and superiority of the country, a rule for action that is aptly expressed in the Trump campaign slogan Make America Great Again. This interpretation of the US mission goes along with an "exemptionalist" America First ${ }^{61}$ view, according to which the US is not bound by rules that apply to other nations. ${ }^{62}$

While this rhetoric is often derided as parochial swagger at the expense of other nations, the globalist variant of the mission imperative has an exceptionalist bend. ${ }^{63}$ It was a nationalist

${ }^{61}$ Nicola Nymalm and Johannes Plagemann, 'Comparative Exceptionalism: Universality and Particularity in Foreign Policy Discourses,' International Studies Review, 21 (2019), p. 22, argue that the America First slogan is an example of Trump's nationalist exemptionalism. ${ }^{62}$ On exemptionalism, see John Gerard Ruggie, 'American Exceptionalism, Exemptionalism and Global Governance,' in Michael Ignatieff (ed.), American Exceptionalism and Human Rights (Princeton: Princeton University Press, 2005), pp. 304-38.

63 American exceptionalism assumes a unique role and character in US history, power exercise, and identity. The trope of exceptionalism and America's benevolent mission shines uncritically through in various descriptions and analyses of US foreign policy strategy and 
respondent (Case 36) who pointed out that

the dominant thinking in the DC policymaking elites ... in both parties. ... [assumes] that the United States has a mission ... to promote democracy and human rights. And while there may be a case-by-case selectivity, there is this [notion of a US] global mission.

A pragmatic liberal think tank analyst further elaborated on this creed ${ }^{64}$ according to which

in the public discourse. See, for example, Dick Cheney and Liz Cheney, Exceptional: Why the World Needs a Powerful America (New York: Simon \& Schuster, 2015); Hilde Eliassen Restad, American Exceptionalism: An Idea that Made a Nation and Remade the World (London: Routledge, 2014); and Hilde Eliassen Restad, 'Are We Coming to the End of "American Exceptionalism"?' Newsweek, 6 March 2016.

64 Exceptionalist actions and beliefs have been used as cause or effect in describing, explaining, or legitimizing the particularities of US history, society, foreign policy, and national identity, see Seymour M. Lipset, American Exceptionalism: A Double-Edged Sword (New York: W. W. Norton, 1997). The concept is based on assumptions about qualitative and quantitative differences of the United States as being universal, unique, exempt, or 
the United States has a democracy, stands for goodness, [US values] are not just American norms but are all universal norms. If you can create a global system wherein those virtues get expanded and internalized by an ever-larger number of countries around the world, [the assumption follows that] you will get this more peaceful and more prosperous world. ...That [belief] has been the consensus among the foreign policy elite, about how to go about doing that [expansion of the American system] (Case

superior. For a critique, see, for example, Godfrey Hodgson, 'Anti-Americanism and American Exceptionalism,' Journal of Transatlantic Studies 2 (2004), pp. 27-38. Exceptionalism often is linked to beliefs about a specific US responsibility, mission, burden, or model function, referring to specific features of US history, practices, values, institutions, and conditions, such as geography, resources, power, opportunities, options, and sacrifices. See, for example, Harold H. Koh, 'America's Jekyll-and Hyde Exceptionalism,' in Michael Ignatieff (ed.), American Exceptionalism and Human Rights (Princeton: Princeton University Press, 2005), pp. 111-44. Ideological convictions, historical mythologies, cultural stereotypes, and topoi related to exceptionalism are "manifest destiny," "the Shining City upon a Hill," "the beacon of the West," "mankind's last best hope," "God's own country," "the indispensable nation," "benign leader of the free world," and the like, see Godfrey 
27/Pragmatic Liberal).

In this study, realists (even hard-nosed ones) favored a more "exemplarist" view of the US mission, namely to teach the rest of the world that following US ideas, principles, policies, and institutions can lead to national greatness, military power, economic prosperity, and individual happiness. In contrast, liberals and some pragmatic liberals typically followed a "vindicationalist" 65 interpretation of mission, meaning that it is a duty and right of the United States to spread its way of life and its institutions, if necessary by force. This notion is based Hodgson, The Myth of American Exceptionalism (Yale University, 2009); and Stephen M. Walt, 'The Myth of American Exceptionalism', Foreign Policy, 189 (2011), pp. 72-5. Exceptionalism has been used to justify unilateral military intervention as well as principled multilateralism to encourage altruistic cooperation and peace, see Stewart Patrick, 'Multilateralism and Its Discontents: The Causes and Consequences of US Ambivalence,' in Stewart Patrick and Shepard Forman (eds), Multilateralism and US Foreign Policy: Ambivalent Engagement (Boulder, CO: Lynne Rienner, 2002), pp. 1-46; Paul Pillar, Why America Misunderstands the World (New York: Columbia Press, 2016); and Sevasti-Eleni Vezirgianniodu, 'The United States and Rising Powers in a Post-hegemonic Global Order,' International Affairs, 89:3 (2013), pp. 635-51. 
on a 'fundamental belief in the rightness of American political values and a belief in democracy and fundamental rights, and a desire .... to promote actively those values [abroad]' (Case 31/Pragmatic Liberal). As mentioned, this rule for action was often expressed in moralistic and idealistic language, evidenced by the experts' references to the benign or otherwise well-intentioned means and purposes of US foreign policy. ${ }^{66}$

In the interviews, many realists, pragmatic liberals, and liberals confirmed the role that exceptionalism plays in US foreign policy thinking and recognized its presence in the public media, in popular culture, among members of Congress, think tank pundits, diplomats, and other experts. Even if perceived as having little impact on actual policy decisions,

${ }^{65}$ Hal W. Brands, What America Owes the World: The Struggle for the Soul of Foreign Policy (Cambridge: Cambridge University Press, 1998).

66 The belief in the US as a benign superpower whose hegemony - unlike that of previous empires - is resting not only on self-interest and military-economic domination but also on liberal norms and universal values is confirmed in the literature, see Thomas Diez and Ian Manners, 'Reflections on Normative Power Europe,' in Felix Berenskoetter and M.J. William (eds), Power in World Politics (London: Routledge, 2007), pp. 173-88. 
at least it [exceptionalism] is a core belief amongst probably most political leaders and foreign policy practitioners. You can find some exceptions. Did Nixon and Kissinger believe in American exceptionalism the way I would define it, no, probably not. Does Trump? Certainly not! But generally speaking? Yes, I think so (Case 32/Pragmatic Liberal).

Only very few interviewees denounced the notion that the US has a mission as merely an attempt to give the pursuit of national US interests an appearance of benevolence (Case 13/Realist), or as 'hypocrisy' because the country is not 'living up' to its own values (Case 24/Pragmatic Liberal, similarly Case 29/Liberal and Case 33/Realist). Another respondent criticized the notion that US foreign policy should be guided by a 'special set of rules' as 'exemptionalist' (Case 9/Liberal). A non-US think tank expert complained about the abuse of exceptionalism. Referencing Walter Russell Mead, ${ }^{67}$ he commented scornfully that 'it [America] is ... an ideological power that seeks to promote its set of values even at the expense of completely destabilizing the whole world upside-down' (Case 17/Realist). Such harsh judgment was very untypical. Instead, even the few (mostly academic) critics of a US

\footnotetext{
${ }^{67}$ Walter Russell Mead, Power, Terror, Peace, and War: America's Grand Strategy in a World at Risk (New York: Vintage, 2005).
} 
mission reacted rather defensively to point out that exceptionalist mission thinking was present in other nations too.

When asked if they believed the American public shared their sense of mission, respondents agreed that American public opinion was more likely in favor of an exemplarist interpretation. ${ }^{68}$ An expert commented that the American public - while not adverse to being told it is exceptional - was inclined to appraise US foreign policy by its perceptible costs and palpable domestic benefits, ${ }^{69}$ not with blind trust in the foreign policy community's benevolent mission to uphold the international order, for which many Americans resonating Trump - felt little attachment (Case 37/Realist).

Regardless of this known reticence among the US public, the great majority of the globalist

${ }^{68}$ According to PEW polls the US public, in comparison to its elites, shows little appetite for empire or moral proselytizing abroad, see Andrew Kohut and Bruce Stoker, The Problem of American Exceptionalism, PEW Research Center, 9 May 2006.

${ }^{69}$ For a similar observation about how the public evaluates foreign policy through a domestic lens, see James Curran, "Americanism, not Globalism": President Trump and the American Mission (Sidney, Australia: Lowy Institute, July 2018), p. 17. 
experts agreed that the US has a mission and/or responsibility to sustain an international order of its own creation and for its own survival. This conviction also led realists, pragmatic liberals, and liberals to criticize the - in their view - exemptionalist inward orientation, swagger, and jingoism of nationalists. This accord corroborates the blob thesis. However, the degree of legitimacy of the mission rule for action and the best way to accomplish it through vindicationalist or exemplarist action was contested between realists, pragmatic liberals, and liberals in accordance with the polarization thesis.

\section{Main Characteristics of Respondent Types}

From observable regularities of the interviewees' positions toward the five rules for action listed above, the following main characteristics of the four expert types can be established: In this study, respondents who expressed support or sympathy for an anti-globalist, protectionist, values-indifferent agenda of US power and patriotic fervor were labelled "nationalist." They pessimistically worried about the bad intentions of other nations and leaders but optimistically claimed that a more aggressive and frequently unilateral approach in foreign policy would safeguard US interests better and help the US to prevail in a fiercely competitive global environment. They defended major elements of Donald Trump's agenda, such as his veneration of national sovereignty, his complaint about lament of ungrateful 
NATO allies taking advantage of the US, the supposedly unfair trade practices of competitors, and the nation-building policy mistakes of his presidential predecessors. At the same time, three of the four nationalist respondents disapproved of Trump's blunt attentiongetting communication style, bombastic rhetoric, and his often unpredictable, jumbled, and mercurial character and decision making. ${ }^{70}$

In general, experts who were in favor of securing US primacy through a policy of strength with a focus on maintaining security alliances but skeptical of multilateral commitments, favoring prosperity through free trade, supporting an exemplarist mission while rejecting an active promotion of values through intervention were identified as "realist." For them the US responsibility is to promote its short and long-term interests against competitors and foes alike in a world ruled by the objective laws of brittle human nature. In general, realists (and

${ }^{70}$ In the sample, only two respondents suppressed any open criticism of Trump although they were in favor of upholding the rules-based international order (Case 30/Realist, Case 31/Pragmatic Liberal). They possibly silenced their criticism because of an expectation of being hired by the Trump Administration and, therefore, not wanting to expose themselves or leave traces of disloyalty in the interviews. Other contacted Trump supporters unfortunately did not respond or participate in the study. 
nationalists) had a more pessimistic Hobbesian world view according to which historical success and the security of a society is ultimately determined by national interest and military power - though not only and not always. ${ }^{71}$

Respondents in support of both a mix of realist and liberal imperatives were labelled as "pragmatic liberals."72 Their opinions often came with a ring of opportunism, aloofness, and skepticism. Many appeared to be cautious and seemed to not want to take an ideological stand on issues. Compared to realists and liberals, pragmatic liberals appeared to be more willing to change their positions depending on a specific purpose, situation, or circumstance. Often pragmatic liberals combined pragmatic no-nonsense, even hardnosed realist attitudes with views borrowed from the internationalist perspective of liberals. For example,

${ }^{71}$ See also Felix Berenskoetter, 'Mapping the Mind Gap: A Comparison of US and European Security Strategies,' Security Dialogue, 36 (2005), p. 75.

72 The small size of the sample did not allow to distinguish further nuanced patterns within this group but it appeared that they represented positions across non-party and party lines including, for example centrist Democrats and moderate Republicans willing to reach across the aisle in favor of situational pragmatic bipartisan rather than ideological and value-driven solutions, or power-maximization. 
pragmatic liberals would situationally be in favor of either soft or hard power tools, pursue unilateralism or multilateralism, or strike a win-win balance between advancing US national interests and human rights values at the same time. In some cases, this attitude may also be an indication of non-commitment, that is upholding norms only rhetorically as an ideal or simply claiming well-meant intentions.

Experts categorized as "liberal" stressed the supposedly "noble" or "benign" intentions and exceptional goodwill of the United States to champion progressive Wilsonian or Kantian ideals of international leadership through engagement, cooperative multilateralism, prosperity through regulated free trade, and the promotion of democracy, and universal values like human rights. They considered US institutions and values as unique and exceptional in certain aspects. As the most powerful player in the international system they also believed the United States has a global responsibility, if not a vindicationalist mission, to uphold the international order and protect the global commons against global threats like climate change, poverty, terrorism and the like as well as against immoral and unjust adversaries who oppose American "universal" goals and values.

As explained in the previous sections, realists, pragmatic liberals, and liberals, including members of the Republican and Democratic Party, put a clear distance between their own 
understanding and support of the post-WWII international order and what they saw as unworkable and antagonizing nationalist policy agenda and slogans like "America First." Several respondents pointed out that other members of the foreign policy community, including those in the Trump administration, shared their critical views. ${ }^{73}$ In other words, regardless of party membership or ideological inclination a gulf separated these "globalists" from Donald Trump and his nationalist followers' agenda of a zero-sum competitive struggle

${ }^{73}$ A pragmatic liberal (Case 7, Think tank) intimated that even Republicans 'holdovers' from the Reagan and GW Bush Administration among President Trump's inner circle felt alienated. Another think tank member pointed out, that many senior level administrators in the DOD and the State Department continue to believe in the liberal international order (Case 32/Pragmatic Liberal). In fact, ten experts said that several of Trump's (at the time mostly military) advisors tried to curb the worst instincts of the President. Among them, a nationalist 
of nations, enterprises, and leaders. ${ }^{74}$ As we have seen, interpretation differences about

commented on the irony that traditional mainstream and liberal Conservatives - only a little more hawkish than Obama - who 'would never have dreamed of supporting Trump in the [Republican] Primary' elections (Case 36/Nationalist), now work in the Trump Administration to restrain the President. Similar observations are reported by Bob Woodward, Fear: Trump in the White House (New York: Simon \& Schuster, 2018).

74 The distance between the US foreign policy elite and Donald Trump and his supporters also has been observed in the literature, see Daniel S. Hamilton and Teija Tiilikainen, Domestic Determinants of Foreign Policy in the European Union and the United States (Washington, DC: Center for Transatlantic Relations and Finnish Institute of International Affairs, 2018), pp. 7-8, 76, 103; A. Trevor Thrall, 'Beyond Hawks and Doves: Identifying the Restraint Constituency,' in A. Trevor Thrall and Benjamin H. Friedman (eds), The Case for Restraint: US Grand Strategy for the 21st Century (New York: Routledge, 2017); Dina Smeltz, Ivo Daalder, Karl Friedhoff, and Craig Kafura, What Americans Think about America First, Results of the 2017 Chicago Council Survey of American Public Opinion and US Foreign Policy, Chicago Council on Global Affairs, 2017, pp. 13-4; Schultz, 'Perils of Polarization for US Foreign Policy;' Busby and Monten, 'Has Liberal Internationalism been 
nominal identical rules for action also existed between realists, pragmatic liberals, and liberals supporting the notion of the existence of a partisan and ideological polarization. At the same time their unmitigated opposition against nationalist positions justified their categorization as the blob.

\section{Summary and Outlook}

The purpose of this article was to present the findings from 37 qualitative interviews in Fall 2017 that help us to better understand the dimensions that characterize US grand strategy imperatives a.k.a. rules for action during a time of enormous shifts in domestic and international relations after Donald Trump became president. Two seemingly contradictory explanations, the blob and the polarization theses have attempted to explain foreign policy elite perceptions. The reconstructivist methodology used to analyze the interviews revealed Trumped?'; and John Halpin et al., America Adrift (Washington, DC: Center for American Progress, 2019); Joshua D. Kertzer et. al., 'Elite Misperceptions and the Domestic Politics of Conflict,' 8 January 2020, http://people.fas.harvard.edu/ jkertzer/, accessed 9 March 2020. 
both strengths and weaknesses in these explanations. While each thesis captures elements of prevailing grand strategy rules for action among experts, each lacks a comprehensive explanation of the commonalities and differences as well as shortcomings and conflicts inherent to these imperatives.

The polarization thesis ignores that realists, pragmatic liberals, and liberals, i.e., the globalists, all agree with the postwar international order's five rules for action, defending them against Trump's nationalist challenge. The blob thesis, on the other hand, ignores the existence of continuous ideological and partisan cleavages that divide the globalists among themselves in their interpretation of the order's imperatives.

Because the definition, meaning, and implementation of the five salient rules for action among the expert interviewees were so broad, they allowed for a variety of respondent interpretations, even contradictory ones; for example, the how, where, when, and why of soft and hard power use while exercising global leadership/primacy. Similarly, different understandings existed among the four expert types of who should be considered an ally, the degree of uni- or multilateralist policies, and the engagement with allies and foes alike. Regarding the prosperity rule, the balancing of domestic with foreign policy needs, the degrees of regulation, the purposes of trade compacts, and its main beneficiaries were 
contested. Different interpretations also applied to the two ideational values and mission rules for action. The meaning, importance, legitimacy, and implementation of "universal" values versus national interests, and how the US foreign policy mission is defined, legitimated and should be practiced was in dispute. These disagreements reflect inherent conflicts between the five rules for action, such as pursuing power politics to implement national interests and, at the same time, upholding values like democracy, justice, and human rights. ${ }^{75}$

Nationalists stood out because they opposed the globalist notion of multilateral and cooperative arrangements of sharing power and prosperity as being naïve and detrimental to US interests and dominance. The hard-nosed Machiavellian position about zero-sum transactional relationships with their followers and foes alike, leads nationalists also to discount the usefulness of values in setting the US foreign policy grand strategy as limiting the exercise of its superpower and sovereignty. Similarly, nationalists unabashedly advocated for the exemptional greatness of the United States over the globalists

${ }^{75} \mathrm{~A}$ realist expert also makes this point, arguing that 'there has been always a struggle between those different priorities in each administration $[\ldots]$ the balance of hard power with human rights concerns, the nature of the regimes we are dealing with ...' (Case 37/Realist). 
vindicationalist or exemplarist mission imperatives.

How can we explain the findings that realists, pragmatic liberals, and liberals differ in their interpretation of the liberal order grand strategy but at the same time are expressing a consensus in support of this order against the nationalist insurgency? According to Dye and Zeigler's elite theory, the maintenance of political, social, and ideological power is an elite's priority. Because Trump is questioning the imperatives of the postwar world, the order's supporters see this as an existential threat to their fundamental creed and existence, regardless of their own partisan and ideological disagreements which 'are largely limited to means of achieving common [globalist] goals. ${ }^{176}$ In addition, since Trump won his office as an anti-elitist outsider attacking the professional foreign policy class in DC, he created a "rally around the flag" effect, alienating experts of all convictions and - ironically - also made it difficult to staff his administration with loyal supporters.

${ }^{76}$ See Dye and Zeigler, 'The Irony of Democracy,' p. 12. However, Gries disagrees and argues that so-called liberal idealists and realists can be distinguished by how they treat policy ends and means. The former focus on the ends whereas the latter on the means, see Peter H. Gries, The Politics of American Foreign Policy: How Ideology divides Liberals and Conservatives over Foreign Affairs (Stanford, CA: Stanford University Press, 2014), p. 109. 
What explains the reticence of the interviewed realists, pragmatic liberals, and liberal experts in developing an alternative narrative beyond the postwar US-centric international order as response to the nationalist challenge? From the interviews it became clear that most respondents believed the postwar order had successfully served US interests and values and it would continue to do so. ${ }^{77}$ While embracing the benefits of the international order, realists, pragmatic liberals, and liberals were at the time of the interviews in Fall 2017, still unprepared to respond to Donald Trump's nationalist agenda with a new strategic narrative. One of the reasons for their defensive attitude was the shock of Trump's election. Many interviewees stated that before his election they had not realized the danger posed by nationalism, nor had they thought about the origins and causes of Trump's success or contemplated how to respond to his insurgency.

Instead, the comments of some interviewees displayed vague hopes that the damages of the Trump administration's foreign policy could be somehow mitigated by the moderating influence of the so-called "adults" in the White House, reasonable voices in Congress, or the

\footnotetext{
${ }^{77}$ Similar Jack Thompson, 'Understanding Trumpism: The New President's Foreign Policy,' Sirius, 1:2 (2017), pp. 1-6.
} 
Mueller investigation that had started in May 2017. ${ }^{78}$ These wishes were at the same time often mixed with palpable pessimism about the irreparable effects of Trump's policies combined with a gloomy "present at the destruction" posture about the vanishing fortunes of the globalist international order.

Other respondents expressed the hope that after Trump, the postwar, US-centric world order somehow could be revived to its previous glory through some miraculous "snap back" to the status-quo ante where supposedly US benevolence and good intentions ruled. ${ }^{79}$ Altogether, globalists, like those sampled in this study in Fall 2017, did not critically reflect on their rules for action nor were they ready to formulate foreign policy alternatives.

78 According to Porter these hopes among the foreign policy elite faded quickly because Trump undauntedly enacted his campaign promises against the elite's opposition and advice, see Porter, 'Why US Grand Strategy has not Changed,' pp. 38-45.

${ }^{79}$ See Doug Stokes, 'Trump, American Hegemony and the Future of the Liberal International Order,' International Affairs, 94:1 (2018), p. 134. However, shortly after Trump's term started, already some conservative Democrats hinted that a "snap back" option is unlikely, see Madeleine Albright and Stephen Hadley, Submitted Statement, Committee on Armed Services, United States House of Representatives (21 March 2017). 
Because international relations are rapidly changing, partially as a consequence of Trump's foreign policy, it is unlikely that US foreign policy can or will simply turn back the clock to a "business as usual" after Trump is out of office in 2020 or $2024 .{ }^{80}$ Cosmetic changes to the postwar grand strategy, like a reconstitution of the old consensus via re-emphasizing of soft power values or more restraint, may not suffice either. Therefore, the criticism of Walt, Mearsheimer, Carpenter and other senior academic commentators and analysts remains valid. ${ }^{81}$

In fact, together with the ceaseless dismantling of the rules-based order by Trump since taking office in January 2017, it appears the Beltway's consensus on reviving the postwar order in its pre-Trump form shows signs of dissolution. For example, a discussion has started among ideological and partisan groups from left to right about how to deal with the

${ }^{80}$ See Ian O. Lesser, 'What to Expect from the United States: A Look Ahead at US Foreign Policy,' IAI Papers, 2 (2020), pp. 1-10.

${ }^{81}$ See footnote 3. A RAND study also has laid out some options for a post-liberal new world order 2.0., see Michael J. Mazarr, Miranda Priebe, Andrew Radin, and Astrid Stuth Cevallos, Alternative Options for US Policy toward the International Order (Santa Monica, CA: RAND Corp, 2017). 
shortcomings of the international order grand strategy and what to put in its place after Trump. ${ }^{82}$ These voices recognize that whether caused by outside forces not controlled by the US, by inability, incompetence, or domestic deliberate action, a collapse of central pillars of a fragmenting international order could lead to a new world order that is based on rules for

${ }^{82}$ Progressive voices are Jentleson, Kizer, vandenHeuvel, Sachs, Sanders, and Warren. Libertarians are represented mostly by the Cato Institute, such as Ashford, Carpenter, Glaser, and Preble. Supporters of (neo)realist conservative policies of restraint, retrenchment, and offshore balancing are Bacevich, Handle, Layne, Mearsheimer, Posen, Ruger, and Walt. 
action that are less favorable to US interests. ${ }^{83}$

From the perspective of elite theory, however, a certain scepticism is advisable. How realistic is the expectation that the prevailing inertia and group think mentality among the foreign policy expert class in DC eventually will give way to a burgeoning pluralist grand strategy debate? It is not yet clear if the "mainstream" foreign policy community is recognizing past errors and is ready to make fundamental adjustments to US foreign policy toward a peaceful, sustainable, and stable new international order where the pursuit of

Many moderate Democrats in favor of competitive geopolitics like Rapp-Hooper, Rhodes, Sullivans have gathered in the so-called National Security Action. Conservative defenders of the status quo ante can be found among American Affairs and some of its defenders are Brands, Brooks, Haass, Ikenberry, Lind, Stokes, Wohlforth. Conservative nationalists can be found in the Heritage Foundation, American Enterprise Institute, Breitbart and are represented by academics like Dueck and Schweller. For a review of the debates and positions, see, for example, Emma Ashford and A. Trevor Thrall, 'The Battle Inside the Political Parties for the Future of US Foreign Policy,' (Washington, DC: CATO Institute, 2018); A. Trevor Thrall and Jordan Cohen, 'The Democrats' Search for a New Foreign Policy' (Cato at Liberty Blog, January 16, 2020), https://www.cato.org/blog/democrats- 
national interests aligns with multilateralism, international law, and values, like human rights. A reform of the traditional grand strategy consensus is influenced by many imponderables, not least the continuing belief in America's exceptionalist mission and primacy as well as the seductive allure of nationalism à la Trump. ${ }^{84}$

As, with any scientific approach, the findings presented in this study are incomplete and limited in their scope. ${ }^{85}$ However, they do demonstrate the value of qualitative studies and

search-new-foreign-policy, accessed 9 March 2020; and Colin Dueck et.al., 'Policy Roundtable: The Future of Conservative Foreign Pol/icy,' Texas National Security Review (2018), https://tnsr.org/roundtable/policy-roundtable-the-future-of-conservative-foreignpolicy/, accessed 9 March 2020. 
the utility of the reconstructivist method in developing an empirically grounded typology to describe the dimensions that characterize US grand strategy imperatives during a time of enormous shifts in domestic and international relations. Complementing earlier leadership studies and contemporary large quantitative surveys, these in-depth interviews provide additional rich insights for policy analysis about the complex reasonings of elites. Such studies deserve consideration in future empirical investigations that will hopefully test and refine the outcomes presented here since a more detailed knowledge of elite beliefs will allow to deeper comprehend the direction US foreign policy may take in the future. ${ }^{86}$

${ }^{83}$ For example, R. David Harden, 'America Adrift: Trump has Ended the 'Post-World War II Era',' The Hill (October 16, 2019); Hilde Eliassen Restad, ' Whither the "City Upon a Hill'? Donald Trump, America First, and American Exceptionalism', Texas National Security Review, 3(1) (2019), https://tnsr.org/2019/12/whither-the-city-upon-a-hill-donaldtrump-america-first-and-american-exceptionalism.

${ }^{84}$ Some critics of US foreign policy are pessimistic about a fundamental reform of US grand strategy and the willingness of the US American public and elite to accept that a multi- 
centric world of equals is incompatible with the belief that being number one is the only option. For example, the Australian James Curran claims that 'America will not become a "normal nation". It will not lose entirely that sense of special mission, simply because that part of its national creed runs so deep and because those in the foreign policy elite are creatures of their culture: the America in which they came to maturity and in which their world view was formed was the America of Kennedy, Johnson, Reagan, and Clinton. The Washington elite will not easily lose their taste for being a superpower. They will cling tightly to the vision and vigor inherent in the description of the United States as the "indispensable nation",' see James Curran, 'Americanism, not Globalism,' p. 16. A promoter of American exceptionalism 3.0 is Charles A. Kupchan, 'The Clash of Exceptionalisms. A New Fight over an Old Idea,' Foreign Affairs, March/April (2018), pp. 139-148.

${ }^{85}$ As mentioned, the placement of individual expert's beliefs by type and rule for action is approximate. Also, the investigator would have preferred more nationalists represented in this study.

${ }^{86}$ The case for a better integration of humanities, social sciences, and mixed methods in policy analysis is eloquently made by Michael Desch, Cult of the Irrelevant: The Waning Influence of Social Science on National Security (Princeton, Princeton UP, 2019). 
Table 1: US Grand Strategy Rules for Action by Expert Type

\begin{tabular}{|c|c|c|c|c|}
\hline \multirow{3}{*}{$\begin{array}{l}\text { GRAND } \\
\text { STRATEGY } \\
\text { RULES FOR } \\
\text { ACTION }\end{array}$} & \multicolumn{4}{|c|}{ EXPERT TYPE } \\
\hline & \multirow{2}{*}{ Nationalists $(\mathrm{N}=4)$} & \multicolumn{3}{|c|}{ Globalists } \\
\hline & & Realists $(N=10)$ & $\begin{array}{c}\text { Pragmatic } \\
\text { Liberals } \\
(N=14)\end{array}$ & Liberals (N=9) \\
\hline $\begin{array}{l}\text { Interpretations } \\
\text { of the } \\
\text { Leadership } \\
\text { Imperative }\end{array}$ & $\begin{array}{l}\text { - Rejecting global order } \\
\text { leadership obligation } \\
\text { - Seeking US } \\
\text { supremacy through } \\
\text { zero-sum power } \\
\text { politics against foes \& } \\
\text { competitors alike } \\
\text { - Priority of economic } \\
\text { and military tools } \\
\end{array}$ & $\begin{array}{l}\text { - Primacy through } \\
\text { offshore balancing \& } \\
\text { military deterrence } \\
\text { - Promotion of a } \\
\text { secure rules-based } \\
\text { order } \\
\text { - Priority of hard } \\
\text { power tools. Soft } \\
\text { power use if } \\
\text { opportune }\end{array}$ & $\begin{array}{l}\text { Mix of } \\
\text { Realist and } \\
\text { Liberal } \\
\text { positions }\end{array}$ & $\begin{array}{l}\text { - Leadership through } \\
\text { engagement } \\
\text { - Promotion of a stable rules- } \\
\text { based order } \\
\text { - Priority of soft power tools } \\
\text { but hard power also used to } \\
\text { maintain order \& promote } \\
\text { human rights }\end{array}$ \\
\hline $\begin{array}{l}\text { Interpretations } \\
\text { of the Alliance } \\
\text { Imperative }\end{array}$ & $\begin{array}{l}\text { - Uni- or bilateral action } \\
\text { preferred \& avoidance } \\
\text { of multilateral treaty } \\
\text { obligations } \\
\text { - Priority of national } \\
\text { sovereignty. Prefers } \\
\text { opportunistic alliances }\end{array}$ & $\begin{array}{l}\text { - Instrumental } \\
\text { multilateralism } \\
\text { - Priority of US } \\
\text { national security \& } \\
\text { collective stability } \\
\text { through flexible } \\
\text { coalitions } \\
\end{array}$ & $\begin{array}{l}\text { Mix of } \\
\text { Realist and } \\
\text { Liberal } \\
\text { positions }\end{array}$ & $\begin{array}{l}\text { - Cooperative multilateralism } \\
\text { - Priority of collective } \\
\text { security \& integration } \\
\text { through a coalition with } \\
\text { liberal democratic states } \\
\text { (Democratic Peace Theory) }\end{array}$ \\
\hline $\begin{array}{l}\text { Interpretations } \\
\text { of the } \\
\text { Prosperity } \\
\text { Imperative }\end{array}$ & $\begin{array}{l}\text { - Skeptical about free } \\
\text { trade \& globalization } \\
\text { - In favor of } \\
\text { transactional deals } \\
\text { - Protectionist agenda } \\
\text { using tariffs, trade } \\
\text { restrictions, sanctions }\end{array}$ & $\begin{array}{l}\text { - Free global trade and } \\
\text { markets and trade } \\
\text { compacts without } \\
\text { regulations } \\
\text { - Increase US market } \\
\text { share \& business- } \\
\text { friendly } \\
\text { environments }\end{array}$ & $\begin{array}{l}\text { Mix of } \\
\text { Realist and } \\
\text { Liberal } \\
\text { positions }\end{array}$ & $\begin{array}{l}\text { - Free global trade and } \\
\text { markets with regulations to } \\
\text { enhance non-economic } \\
\text { goals (Economic Peace } \\
\text { Theory) } \\
\text { - Uphold standards, like } \\
\text { transparency, labor laws, } \\
\text { environment etc. }\end{array}$ \\
\hline $\begin{array}{l}\text { Interpretations } \\
\text { of the Values } \\
\text { Imperative }\end{array}$ & $\begin{array}{l}\text { - Passive "laissez faire" } \\
\text { attitude about values } \\
\text { agenda as political } \\
\text { tool }\end{array}$ & $\begin{array}{l}\text { - Utilitarian support } \\
\text { for individual \& } \\
\text { freedom rights } \\
\text { - Skeptical about } \\
\text { active intervention } \\
\text { for values } \\
\end{array}$ & $\begin{array}{l}\text { Mix of } \\
\text { Realist and } \\
\text { Liberal } \\
\text { positions }\end{array}$ & $\begin{array}{l}\text { - Universalist promotion of } \\
\text { human rights, democracy \& } \\
\text { humanitarian } \\
\text { intervention/R2P }\end{array}$ \\
\hline $\begin{array}{l}\text { Interpretations } \\
\text { of the Mission } \\
\text { Imperative }\end{array}$ & $\begin{array}{l}\text { - Exemptionalist, } \\
\text { inward oriented } \\
\text { patriotism } \\
\text { - US has no mission or } \\
\text { responsibility for other } \\
\text { nations or intl. order } \\
\text { - US is superior, the } \\
\text { best, bravest, greatest } \\
\text { nation, if it follows } \\
\text { only its interests } \\
\text { - Slogans: America } \\
\text { First, Make America } \\
\text { Great Again }\end{array}$ & $\begin{array}{l}\text { - Exemplarist - US is } \\
\text { a leading force \& } \\
\text { model } \\
\text { - US has a special \& } \\
\text { unique character, its } \\
\text { power, interests, } \\
\text { principles, } \\
\text { institutions, } \\
\text { experiences, and } \\
\text { achievements are } \\
\text { historically singular } \\
\text { - Slogans: Shining } \\
\text { City upon a Hill, } \\
\text { Beacon of the West }\end{array}$ & $\begin{array}{l}\text { Mix of } \\
\text { Realist and } \\
\text { Liberal } \\
\text { positions }\end{array}$ & $\begin{array}{l}\text { - Vindicationalist - outward } \\
\text { oriented, expand the rules- } \\
\text { based international order } \\
\text { - US values, ideals, beliefs, } \\
\text { intentions, goodwill are } \\
\text { unique, universal, and } \\
\text { inherently noble and } \\
\text { benevolent } \\
\text { - Slogans: Indispensable } \\
\text { nation, Protector of the } \\
\text { Weak, Global Superman }\end{array}$ \\
\hline
\end{tabular}

Note: Placement of individual expert's beliefs by type and rule for action is approximate 